\title{
The rabies early death phenomenon: A report of ineffective administration of rabies vaccine during symptomatic disease
}

\author{
Mahmoud Sadeghi, Shams-ali Hadizadeh Moallem', Elham Yousefi-Abdolmaleki², \\ Mohammad Montazeri ${ }^{1}$
}

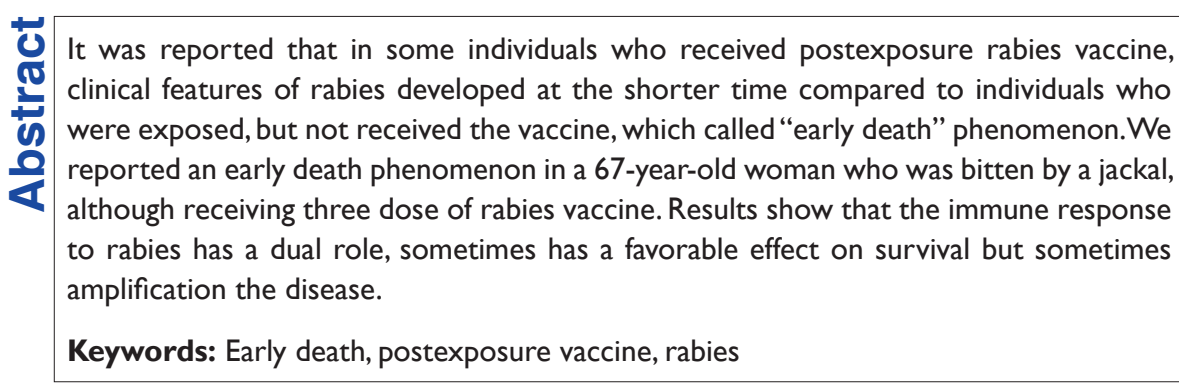

\section{Introduction}

Rabies is a fatal encephalomyelitis that transmitted most commonly through the bite of a rabid animal. Tens of thousands of people around the world die every year from rabies, mostly in developing countries. ${ }^{[1]}$ In a few study, it was reported that in some individuals who received postexposure rabies vaccine, clinical features of rabies developed at the shorter time compare to individuals who were exposed, but not received the vaccine. This phenomenon called "early death." [2] In this article, we report an early death in a patient infected with rabies.

\section{Case Report}

A 67-year-old woman was admitted to the hospital with shortness of breath, headache, fatigue, anorexia and

From:

Infectious Disease and Tropical Research Center, Babol University of

Medical Sciences, ${ }^{1}$ Young Researchers Club, Islamic Azad University, Babol,

${ }^{2}$ Department of Internal Medicine, Faculty of Medicine, Mazandaran University

of Medical Sciences, Sari, Iran

Correspondence:

Dr. Elham Yousefi-Abdolmaleki, Department of Internal Medicine, Faculty of Medicine, Mazandaran University of Medical Sciences, Sari, Iran.

E-mail: elham7755@yahoo.com

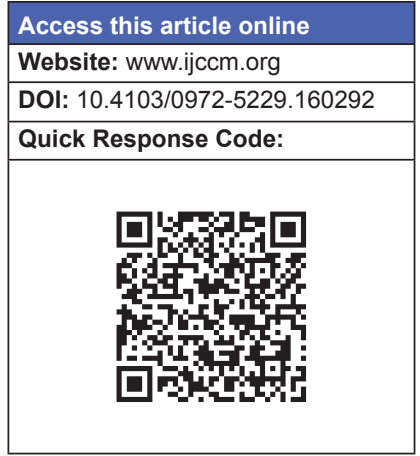

headache. The patient's symptoms began gradually the day before admission and then were aggravated.

The patient had a history of bite of her finger by jackal about 10 days before admission, and three doses of rabies vaccine (Imovax ${ }^{\circledR}$ rabies, Sanofi Pasteur, Iran) was administered as an $1.0 \mathrm{ml}$ injection in the deltoid muscle on days 0,3 , and 7 in conjunction with antirabies serum according to protocol, that is, prescribed by WHO Expert Committee on Rabies. ${ }^{[3]}$ On admission, her vital signs were as follows: Temperature $37^{\circ} \mathrm{C}$, pulse rate $100 / \mathrm{min}$, blood pressure $210 / 110 \mathrm{mmHg}$, and respiration rate $26 / \mathrm{min}$. She was confused, disoriented, with slurred speech and had sialorrhea. Admission laboratory values included prerenal azotemia (blood urea nitrogen level of $54 \mathrm{mEq} / \mathrm{L}$ and serum creatinine

This is an open access article distributed under the terms of the Creative Commons Attribution-NonCommercial-ShareAlike 3.0 License, which allows others to remix, tweak, and build upon the work non-commercially, as long as the author is credited and the new creations are licensed under the identical terms.

For reprints contact: reprints@medknow.com

How to cite this article: Sadeghi M, Moallem SaH, Yousefi-Abdolmaleki E, Montazeri M. The rabies early death phenomenon: A report of ineffective administration of rabies vaccine during symptomatic disease. Indian J Crit Care Med 2015;19:422-4. 
of $1.9 \mathrm{mEq} / \mathrm{L}$ ) with mixed respiratory alkalosis and metabolic acidosis. Results of blood tests were as follows: White blood cell count, $19.0 \times 10^{3} / \mathrm{dL}$ with $86 \%$ neutrophils; hemoglobin, $13.0 \mathrm{~g} / \mathrm{dL}$; serum sodium, 143 $\mathrm{mmol} / \mathrm{L}$; serum potassium, $3.4 \mathrm{mmol} / \mathrm{L}$; serum glucose, $232 \mathrm{mg} / \mathrm{dL}$; and serum calcium, $8.6 \mathrm{mg} / \mathrm{dL}$; serum phosphorus, $2.7 \mathrm{mg} / \mathrm{dL}$; prothrombin time and partial thromboplastin time were normal and procalcitonin were $<0.5 \mathrm{ng} / \mathrm{ml}$.

The initial clinical diagnosis was rabies and ceftriaxone, and acyclovir was initiated. Moreover, sodium valproate, phenytoin, and clonazepam were administrated according to the neurological consultation.

The third hour after admission, tachycardia, tachypnea, and sialorrhea were increased, blood pressure had dropped and cyanosis occurred in the distal parts of upper and lower extremities. The patient level of consciousness was decreased gradually, and myoclonus had started. In the $4^{\text {th }} \mathrm{h}$ of admission, the patient developed respiratory and cardiac arrest and were transferred to Intensive Care Unit after intubation. On the $3^{\text {rd }}$ day of hospitalization, she died despite treatment. To confirm the diagnosis, an autopsy was performed giving more attention to the brain. There were many punctuate hemorrhages and multiple infarcts involving the cortex, basal ganglia, and hippocampus. An acute encephalomyelitis characterized by a lymphohistiocytic infiltrate, perivascular lymphocytic infiltration, and neuronophagia was reported in the cortical gray matter, along with patchy changes in the white matter. Eosinophilic intracytoplasmic inclusion bodies indicative of Negri bodies are present within Purkinje cells, and larger neurons of the brainstem.

\section{Conclusion}

Rabies is a fatal viral disease of carnivorous animals, but warm-blooded animals, and human are believed to be susceptible and is spread by the bites of mammals. The importance of disease due to the high fatality rate, mortality and economic losses that can cause disease in animals, high vaccine cost. ${ }^{[4]}$ Rabies is endemic in the wildlife of Iran and infection frequently transmitted from wildlife hosts to domestic animals. ${ }^{[5]}$ The incubation period of rabies is usually 3-12 weeks. Rabies immune globulin and the first dose of rabies vaccine should be given as soon as possible after exposure since delays in initiating a postexposure prophylaxis reduce its effectiveness, and the disease is almost always fatal. Rabies prophylaxis is very effective documented for correctly completed vaccination series in the USA since cell-purified vaccines have been utilized. ${ }^{[3]}$ However, in recent years, there have been doubts about the safety of rabies vaccines.

It has been proposed that administration of rabies vaccine during symptomatic rabies could be ineffective, and there are concerns about the "early death" phenomenon reported in animals that develop rabies with shorter incubation period after rabies vaccine administration. ${ }^{[2]}$ Early death could be developed during symptomatic rabies by rabies vaccine rabies or transfer of effector cells or antibodies, and cause dominant symptoms and earlier death. ${ }^{[6]}$ It has been shown that infection with replication-deficient rabies viruses, in some animals with a low level of rabies-induced antibody lead to earlier death compared with those without antibody. Similarly, in humans exposed to rabies, individuals who received postexposure immunization develop clinical rabies with shorter incubation period than patients who did not receive the vaccination. ${ }^{[7]}$

The pathophysiology of early death is unknown. This phenomenon can be transferred via spleen cells or plasma of vaccinated animals into infected recipients. ${ }^{[6]}$ It has been proposed that the immunity of the rabies virus during the active disease may lead to immune response convert from noncytopathic antibody-mediated clearance to antibody-dependent cytotoxicity. Significant neuronal loss and demyelination may occur due to the extension of the immune response to the brain. ${ }^{[8]}$ Andral in his study shows that lack of thymus in the mouse prevents early death, but the reduction of B lymphocytes with cyclophosphamide administration has not had any effect on this phenomenon. ${ }^{[6]}$ Results show that the immune response to rabies has a dual role, sometimes favorably on survival but sometimes with amplification of the disease.

\section{Financial support and sponsorship \\ Nil.}

\section{Conflicts of interest}

There are no conflicts of interest.

\section{References}

1. Mani RS, Madhusudana SN. Laboratory diagnosis of human rabies: Recent advances. ScientificWorldJournal 2013;2013:569712.

2. Willoughby RE .Jr. "Early death" and the contraindication of vaccine during treatment of rabies. Vaccine 2009;27:7173-7.

3. Rupprecht CE, Gibbons RV. Clinical practice. Prophylaxis against rabies. N Engl J Med 2004;351:2626-35. 
4. Warrell MJ, Warrell DA. Rabies: The clinical features, management and prevention of the classic zoonosis. Clin Med 2015;15:78-81.

5. Esfandiari B, Youssefi MR, Fayaz A. Serodiagnosis evaluation of rabies and animal bites in North of Iran, 2010. J Gen Mol Virol 2011;3:71-3.

6. Andral B. The early death phenomenon related to sensitization of mice with rabies antigen - Qualitative study and kineties. Comp Immunol Microbiol Infect Dis 1982;5:79-91.

7. Wunner WH. Rabies. In: Schaechter M, editor. Encyclopedia of Microbiology. $3^{\text {rd }}$ ed. Amsterdam: Elsevier Ltd.; 2009. p. 484-99.

8. Willoughby Jr RE. Are we getting closer to the treatment of rabies? Future Virol 2009;4:563-70. 